DOI: $10.15290 /$ bsl.2018.13.05

\author{
Magdalena Dudzińska \\ Wydział Filologiczny \\ Uniwersytet w Białymstoku \\ e-mail: magda_dudzińska@wp.pl \\ ORCID: 0000-0002-1381-2900
}

\title{
Filomacki związek z miejscem - fragmenty geobiografii Michała Rukiewicza i Adama Mickiewicza
}

Związek człowieka z miejscem literatura ujawnia i wyraża od dawna, ostatnio bywa on podkreślany $\mathrm{w}$ literaturoznawstwie $\mathrm{z}$ powodu zwrotu topograficznego ${ }^{1}$. Jednym $z$ jego efektów jest spostrzeżenie, że narzędzia wypracowane $\mathrm{w}$ ramach owego zwrotu okazują się być przydatne nie tylko do badania tekstów powstałych w XX i XXI wieku, ale również dzieł pochodzących z epok dawniejszych, $\mathrm{z}$ uwzględnieniem romantyzmu ${ }^{2}$.

W niniejszym tekście pojęciem, wokół którego toczą się rozważania na temat okresu filomackiego w życiu i twórczości Michała Rukiewicza i Adama Mickiewicza jest geobiografia - zagadnienie szeroko omówione m.in. przez Jacka Kaczmarka, autora książki Podejście geobiograficzne w geografii społecznej. Zarys teorii i podstawy metodyczne. W artykule Geobiografia - historie życia a studia nad migracjami Kaczmarek określił ten termin jako:

\footnotetext{
1 E. Rybicka, Geopoetyka. Przestrzeń i miejsce we wspótczesnych teoriach i praktykach literackich, Kraków 2014, s. 23. Warto zaznaczyć, że na łamach „Białostockich Studiów Literaturoznawczych" 2011 nr 2 ukazał się Zarys geopoetyki Kennetha White'a (przeł. A. Czarnacka, przejrz. B. Kaniewska) oraz studium inicjatorki tego tłumaczenia - Elżbiety Konończuk (O poetyckim zamieszkiwaniu świata według Kennetha White'a).

2 Możliwość czytania romantyzmu przez geopoetykę poświadcza m.in. tom zbiorowy: Georomantyzm. Literatura, miejsce, środowisko, red. E. Dąbrowicz, M. Lul, K. Sawicka-Mierzyńska, D. Zawadzka, Białystok 2015.
} 
szlak życia człowieka przebiegający przez zbiór lokalizacji przestrzennych (miejsc zamieszkania), będących wypadkową oddziaływania środowiska historycznego i społecznego, powodujący jednocześnie powstanie w „sferze myślenia" doświadczenia przestrzennego [...]. Geobiografia to także metoda geografii społecznej, której celem jest poznanie (zrozumienie) życia człowieka, w różnych użytkowanych przez siebie miejscach (ze szczególnym uwzględnieniem miejsc zamieszkania) ${ }^{3}$.

Dla obu bohaterów mojego artykułu związek kolejnych zdarzeń autobiograficznych (bądź też udział w następujących po sobie wydarzeniach „wielkiej historii”) z miejscem przebywania/zamieszkania jest niezwykle wyrazisty, dokładnie zapisany w prywatnej korespondencji i w utworach poetyckich ${ }^{4}$. Literackie i epistolograficzne zapisy tych miejsc składają się, w moim przekonaniu, na „szlaki życia” Rukiewicza i Mickiewicza oraz umożliwiają wytyczenie geobiograficznych map obu filomatów. Do „miejsc zamieszkania” zaliczam utrwalone doświadczenia miejsc, z których pochodzą bądź przebywają w nich Rukiewicz i Mickiewicz, choć w niniejszym artykule mogłam zatrzymać się tylko przy niektórych punktach ich geobiografii.

O Mickiewiczu wiemy niemal wszystko, jesteśmy w stanie odtworzyć każdy etap jego biografii. Michał Rukiewicz to postać wciąż bardzo tajemnicza ${ }^{5}$. O trzy lata starszy od Mickiewicza, rodzi się w miejscowości Hoźna, skąd jako młody chłopak przenosi się do Białegostoku. Przeprowadzka była zapewne związana z sytuacją zawodową ojca - urzędnika rozpoznawalnego w Białymstoku i okolicach. Rukiewiczowie kupują dom nieopodal sławnego Gimnazjum Białostockiego, w którym kilka kolejnych lat swojego życia spędzi przyszły podlaski filomata. Rukiewicz jeszcze przed rozpoczęciem studiów na Uniwersytecie Wileńskim przeżywa niezwykle ważne, pokoleniowe

${ }^{3}$ J. Kaczmarek, Geobiografia - historie życia a studia nad migracjami, "Acta Universitatis Lodziensis. Folia Geographica Socio-Oeconomica” 2004, nr 5, s. 52-53.

4 Jak mówi Sławomir Rzepczyński: „biografia jest nierozerwalnie związana z twórczością, zarówno jako jej naturalny czynnik sprawczy, jak i wewnętrzny element jej [...] struktury" [S. Rzepczyński, Projekt "innego" biografizmu, „Słupskie Prace Filologiczne” 2007, nr 5, s. 174].

5 O Michale Rukiewiczu pisali do tej pory m.in.: S. Niewiński, Pokój cieniom. Ziemi Juchnowieckiej historie nieokrzyczane, Juchnowiec Kościelny 2014; J. Trynkowski, Gimnazjum. Z dziejów Gimnazjum Białostockiego, Białystok 2002; J. Borowczyk, Rekonstrukcja procesu filomatów i filaretów 1823-1824, Poznań 2003; tenże, Zestane pokolenie: filomaci w Rosji (1824-1870), Poznań 2014; S. Bukczyn, Echo pod Białymstokiem, przeł. A. Drawicz, Olsztyn 1982; W. Wróbel, Białostockie ślady Michała Rukiewicza, http://www.naszahistoria.pl/artykuly/a/bialostockie-slady-michalarukiewicza,9412089 [dostęp 14.01.2018]; tenże, Od Karola Zabłockiego do Michela Kona, http:// www.poranny.pl/album-bialostocki/a/od-karola-zablockiego-do-michela-kona,9454915/ [dostęp 14.01.2018], D. Zawadzka, Białystok, w: Atlas Polskiego Romantyzmu, Nowa Panorama Literatury Polskiej, http://nplp.pl/artykul/bialystok-2/ [dostęp 2.07.2017]. 
wręcz, wydarzenie - bierze bowiem udział w kampaniach napoleońskich ${ }^{6}$, co na stałe zaznaczy się w jego biografii, stając się niemal emblematem Rukiewicza. Podejmuje on zatem edukację uniwersytecką mając już za sobą ważne doświadczenie historyczno-przestrzenne, a jako późniejszy członek Towarzystwa Filomatów będzie określany mianem "Szwaliżer" (od szwoleżera), właśnie ze względu na udział w napoleoniadzie.

Rukiewicz to człowiek niewątpliwie związany ze wsią, przyrodą i ziemią, jego przeznaczeniem było zajmowanie się gospodarstwem. Z przyczyn losowych rodzinne plany wobec niego uległy zmianie, jednak po ukończeniu Uniwersytetu okazał się być sprawnym gospodarzem i z powodzeniem zajmował się dzierżawionym w Zawykach folwarkiem. W 1824 został aresztowany w związku ze śledztwem przeciwko filomatom, lecz uniknął wyroku. Po powrocie na Podlasie nie zaprzestał działalności $w$ tajnych związkach i ponownie znalazł się $\mathrm{w}$ więzieniu na skutek udziału w buncie, który wybuchł w jednej z tutejszych jednostek wojskowych (w miejscowości Brańsk), łączonym $\mathrm{z}$ ruchem dekabrystów. Następnie, w myśl wyroku, musiał odbyć dziesięcioletnią katorgę w Czycie i Pietrowskim Zawodzie, by ostatecznie przymusowo osiąść na Syberii, w miejscowości Korkino, w której też zmarł.

Rukiewicz jest więc filomatą niezwykle ruchliwym, który jeszcze przed podjęciem studiów stale zmieniał miejsce pobytu, Mickiewicz zaś do momentu wyjazdu do Rosji pozostawał zwykle na długo związany z określoną przestrzenią i rodzinną okolicą.

Podobne lokalizacje w życiu filomatów można nazwać za Małgorzatą Czermińską miejscami autobiograficznymi, które różnią się od np. pokoleniowych miejsc pamięci (jak Wilno) swoim indywidualnym charakterem, związanym z życiem i twórczością danej osoby. Kategoria miejsca autobiograficznego umożliwia zestawienie rozmaitych, jednostkowych i zbiorowych lokalizacji - omówienie zarówno znaczenia Rosji (czy to europejskiej w wypadku Mickiewicza, czy Syberii Rukiewicza) oraz Europy Zachodniej, jak i okolic związanych z pierwszym etapem biografii filomatów: Białegostoku wraz z pobliskimi miejscowościami (Rukiewicz) oraz Nowogródka (Mickiewicz). Pojęcie to Czermińska definiuje w sposób następujący:

Literackie miejsce autobiograficzne jest znaczeniowym, symbolicznym odpowiednikiem autentycznego miejsca geograficznego oraz związanych z nim kulturowych wyobrażeń. Nie istnieje w geograficznej próżni, nie odnosi się

\footnotetext{
6 Należałby on do napoleońskiego „pokolenia klęski”. Por. D. Zawadzka, Pokolenie klęski 1812 roku. O Antonim Malczewskim i odludkach, Warszawa 2000.
} 
do przestrzeni geometrycznej, uniwersalnej, pustej. Związane jest zawsze $\mathrm{z}$ topograficznym, materialnym konkretem, nawet jeżeli zostanie on poddany przekształceniom literackim, właściwym nie tylko metaforze, możliwej w konwencji realistycznej, ale również prawom oniryzmu i fantastyki ${ }^{7}$.

Kategoria ta jest szczególnie użyteczna w połączeniu z klasyfikacją wyodrębnionych przez badaczkę miejsc autobiograficznych, mogą być one bowiem stałe, poruszone, obserwowane, wspominane, jak również wyobrażone, przesunięte, wybrane, dotknięte ${ }^{8}$. Niektóre $\mathrm{z}$ tych typów miejsc, jak na przykład miejsca przesunięte, poruszone i stałe, są wspólne obu filomatom. Takim punktem wspólnym okazuje się na przykład uniwersyteckie Wilno, w którym dochodzi do spotkania, przecięcia się geobiografii Rukiewicza i Mickiewicza.

Istotnym problemem badawczym $\mathrm{w}$ niniejszym artykule jest też konceptualizacja przestrzeni, zarówno pod względem typów miejsc (mowa tu bowiem o przestrzeni wyobrażonej, rodzinnej, emotywnej, jak i doświadczonej, zapamiętanej, tekstowej ${ }^{9}$ ), jak i form ich utrwalania, zapisywania. Do owych form należy mapa ${ }^{10}$, potraktowana jako narzędzie porządkujące i syntetyzujące prowadzone w tekście rozważania - to na niej zostają bowiem uobecnione geobiografie obu twórców, ona graficznie ujawnia ich „szlaki życia"11. O ile Adam Mickiewicz trwale związany został w wyobraźni czytelników z "nowogródzką stroną", następnie z Wilnem i tamtejszym Uniwersytetem, o tyle obecność Michała Rukiewicza, czy to na rodzinnym Podlasiu, czy w Wilnie, nie jest już sprawą tak oczywistą. Rukiewicz należy bowiem do filomatów obecnie zapomnianych i często pomijanych w portretach pokolenia - nie ma go na przykład w III części Dziadów Mickiewicza. Z rodzinną przestrzenią związał się on jednak niezwykle mocno - po-

7 Zob. M. Czermińska, Miejsca autobiograficzne. Propozycja w ramach geopoetyki, „Teksty Drugie" 2011, nr 5, s. 187. Zob. także E. Rybicka, Geopoetyka, s. 277-296.

8 Tamże, s. 11-17.

9 Na ten temat m.in.: M. Czermińska, Miejsce autobiograficzne, s. 192-199; E. Domańska, Epistemologie pograniczy, w: Na pograniczach literatury, red. J. Fazan, K. Zajas, Kraków 2012; Geografia i metafora, red. E. Konończuk, E. Nofikow i E. Sidoruk, Białystok 2014; J. Kaczmarek, Geobiografia - historie życia; E. Rybicka, Geopoetyka; S. Škrabec, Geografia wyobrażona. Koncepcja Europy Środkowej w XX wieku, Kraków 2013.

10 Por. E. Konończuk, Mapa w interdyscyplinarnym dialogu geografii, historii i literatury, „Teksty Drugie" 2011, nr 5; E. Rybicka, Geopoetyka, s. 9-10; D. Zawadzka, Krajobraz, mapa, pejzaż powinowactwa romantyczne, w: Geografia i metafora.

11 O szczególnej roli mapy pisał m.in. Yi-Fu Tuan, podkreślając równorzędne znaczenie wszystkich miejsc składających się na określoną biografię. Tak więc to narzędzie pozwala na zapisywanie biografii bez przymusu wartościowania konkretnych lokalizacji. Por. Yi-Fu Tuan, Przestrzeń i miejsce, przeł. A. Morawińska, wstęp K. Wojciechowski, Warszawa 1987, s. 190. 
przez filomacką pracę na prowincji (czy też z prowincją). Mapa w przypadku Rukiewicza okazuje się więc poniekąd narzędziem ratowniczym ${ }^{12}$ dla jego geobiografii, pozwala nie tylko odtworzyć (i ocalić od zapomnienia) szlak życiowej wędrówki podlaskiego filomaty, ale też z nowej perspektywy przyjrzeć się Podlasiu jako miejscu, w którym pewne filomackie idee - np. tworzenie tajnych związków w terenie - miały szanse rozwinąć się w sposób może bardziej wyrazisty, niż gdzie indziej. Dla biografii Mickiewicza natomiast mapa stanie się dokumentacją zmiany, jaka zaszła w jego doświadczaniu przestrzeni od chwili rozpoczęcia nauki na Uniwersytecie Wileńskim. $\mathrm{W}$ obu biografiach związek z przestrzenią oraz zaznaczanie miejsc autobiograficznych na mapie staje się równocześnie sposobem na przedstawienie filomackiej wspólnoty losów oraz topografii indywidualnych doświadczeń jej członków.

Niewątpliwie do najbardziej rozpoznawalnych filomatów należy Adam Mickiewicz - to właśnie w Towarzystwie rozwijał się jego talent literacki, a także nawiązywały przyjaźnie, dzięki którym poeta mógł znaleźć wsparcie podczas trudnego dla niego okresu pobytu w Kownie. Towarzystwo Filomatów, a także sam Uniwersytet, stały się głównymi środowiskami formującymi Mickiewicza i punktami odniesienia podczas jego późniejszych podróży. Wprawdzie od 1819 roku, a więc od momentu wyjazdu do Kowna, kontakt poety z filomatami opierał się przede wszystkim na korespondencji, jednak to właśnie w tym czasie najwyraźniej umacnia się filomacka przyjaźń, a dotąd teoretyczne założenia Towarzystwa, dotyczące prowadzenia szerszej działalności edukacyjnej, zwłaszcza na prowincji, mogą zostać wcielone w życie. Również ten właśnie aspekt aktywności Towarzystwa Filomatów zdawał się być najistotniejszy w życiu Michała Rukiewicza.

Do Towarzystwa Filomatów Rukiewicz zostaje wprowadzony przez Onufrego Pietraszkiewicza w październiku 1819 roku, jednak w spotkaniach uczestniczy nieformalnie już od kwietnia. Rukiewicz zaznaczył swoją obecność w gronie "miłośników nauki” jako osoba stojąca na straży ustalonych przez współtowarzyszy zasad, a także jako ten, któremu niezwykle bliskie były zarówno dalsze losy organizacji, jak i podkreślanie jej roli w życiu studentów. Wyrazem tak znacznego zaangażowania Rukiewicza w działania Towarzystwa Filomatów jest m.in. pieśń Hejże, bracia Filareci, wiersz Wspo-

12 Por. E. Domańska, Historia ratownicza, „Teksty Drugie” 2014, nr 5. 
mnienie, będący poetyckim zapisem jego autobiografii, gdzie również przywołany został czas pobytu na Uniwersytecie Wileńskim oraz Pacierz promienisty ${ }^{13}$, stanowiący swego rodzaju uzupełnienie teorii promionków ${ }^{14}$ Tomasza Zana. Aktywność Rukiewicza w Towarzystwie Filomatów jest szczególna głównie dlatego, że od początku zostaje nakierowana na późniejsze działania na prowincji, w okolicach Białegostoku. Można się zastanawiać, czy to właśnie nie Rukiewicz najpełniej zrealizował leżące u podstaw filomatyzmu założenia dotyczące regionalnego i konkretnie ulokowanego charakteru działalności filomatów.

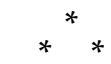

Jak pisała Maria Dunajówna w pracy Filomaci na prowincji: „postaci filomatów i filaretów kojarzą się w naszych wspomnieniach przeważnie z murami Wilna. Mniej się pamięta o wsiach i miasteczkach, które gościły w swym obrębie członków związków wileńskich"15. Zauważywszy ten problem, Dunajówna postanowiła przypomnieć pomijane często miejsca, w których filomaci wcielali $\mathrm{w}$ życie projekty powstałe jeszcze $\mathrm{w}$ murach uczelni. Między innymi, właśnie dzięki jej badaniom, powstaje szczegółowy opis lokalizacji, w których kolejne towarzystwa zakładał Michał Rukiewicz. Publikacja Filomaci na prowincji rzuca nowe światło na informacje zawarte przez Rukiewicza w liście pisanym do Tomasza Zana, niezwykle istotnym dla dokładnego wyliczenia i charakterystyki miejscowości, które wiązały się z działaniami na Podlasiu. Topograficzne ulokowanie filomacko-dydaktycznej pracy Rukiewicza pozwala bowiem na stworzenie indywidualnej mapy Podlasia, która staje się zarówno wyjątkowym kartograficznym zapisem części geobiografii filomaty, jak również nakreśla obszar działań Towarzystwa i jego kolejnych rozgałęzień $\mathrm{w}$ terenie. Sam Rukiewicz nie szczędzi w listach geobiograficznych informacji, dzięki czemu powstaje komplementarny w stosunku do Wilna obraz dziewiętnastowiecznej, aktywnej, a przy tym nieco konspirującej prowincji. Mamy więc do czynienia z rysowaniem mapy przy pomocy słów dokładna lokalizacja miejscowości, w których działał Rukiewicz, ich topograficzny opis, tworzą literacki plan Podlasia.

Michał Rukiewicz w listach do uniwersyteckich przyjaciół tak relacjonował przebieg swojej działalności w obwodzie białostockim:

\footnotetext{
13 Poezja filomatów, t. 1, oprac. J. Czubek, Warszawa 1922, s. 302-303.

14 T. Zan, Teoria promionków i majówki Promienistych, w: Promieniści - filomaci - filareci, oprac. H. Mościcki, Warszawa 1916, s. 47-52.

15 M. Dunajówna, Filomaci na prowincji, Wilno 1935, s. 6.
} 
Ponieważ ani w Grodnie, ani w Białymstoku, miastach guberskich żadnych zabaw nie rozpoczęto, więc postanowiliśmy w środku między tymi dwoma miastami rozpocząć zabawy. Jest właśnie o mil 6 od Grodna i 6 od Białegostoku na wielkim trakcie powiatowe miasteczko Sok[ó]łka, gdzie się zawsze dość dobrze bawią i gdzie się już kilka redut odbyło; więc i my tam. W okolicach tego miasteczka mieszka kilka osób, zabawy lubiące; muszą więc z nami brykać i hulać. Muzyka choć nieliczna, bo z kilku złożona, zdaje się, że będzie dobra. Muzykanci, jakkolwiek nie artyści i trochę do grania leniwi, zdaje się, że w takt grać będą, choć mniej hucznie, ale zapewne w dwóch mniej salach słyszeć będzie można. Spodziewać się, że przy takiej muzyce rzadko kto się wywróci, a ucznie p. Dziewoniego może się nawet i popisywać będą -....!!!. Mamy jeszcze w naszym białostockim obwodzie dwa powiatowe miasteczka B[i]elsk i Drohiczyn; słychać, że i tam myślą o zabawach, więc z niedzieli wróciwszy z Sok[ó]łki tam pojadę ${ }^{16}$.

List przynosi świadectwo wielkiej gorliwości autora, jego nieustannych wyjazdów - w korespondencji filomatów częste zdanie odnoszące się do Rukiewicza to: „Michał powrócił już z drogi”- i zaangażowania w sprawę filomacką, w poprawę jakości wychowania i kształcenia młodzieży. Pomimo tego doskwiera mu przypadłość, o której szeroko rozpisywał się też Mickiewicz podczas pobytu w Kownie - samotność. Mówi o niej w innych listach do przyjaciół, gdzie zaznacza, że z tak licznymi zadaniami pozostaje na Podlasiu sam, gdy tymczasem jego towarzysze ze studiów kłopoty mogą rozwiązywać wspólnie ${ }^{17}$. Podstawową różnicą w przeżywaniu dojmującego uczucia osamotnienia ich obu jest zarówno odmienny sposób mówienia o nim, jak i wpływ nastroju na sposób postrzegania otaczającej przestrzeni.

Mickiewicz jest swoją samotnością niezwykle przybity, Kowno przytłacza go, a tym samym pełnienie obowiązków wypływających z nauczycielskiego stanu nie tylko nie przynosi mu satysfakcji, lecz przyprawia o jeszcze większą „melancholię". O przeżywanych smutkach szczegółowo pisze przyjaciołom ${ }^{18}$, którzy przychodzą mu z pomocą, wspierają dobrym słowem, nie-

\footnotetext{
16 Korespondencja filomatów, t. 4, oprac. J. Czubek, Kraków 1913, s. 342-343. Wszystkie kolejne cytaty listów filomatów, o ile nie zaznaczono inaczej, pochodzą z tego wydania i dalej będą zaznaczane w tekście głównym za pomocą skrótu KF, cyfra rzymska odsyła do tomu.

17 Rukiewicz wspomina na przykład, że na pewno efektywniejsze są wnioski wysnuwane podczas zebrań niż te, do których dochodzi się samotnie. Por. „Rozmowy wasze codzienne np. przy herbacie więcej wam zapewne wyobrażeń dla was samych i dla ogółu pożytecznych dostarczają, niż moje suche w samotności rozumowania" [KF IV, s. 344].

18 „Ale ja bywam tu nudny, zły, jednym słowem nieszczęśliwy, tego wy nigdy, w Wilnie siedząc nie pojmiecie. Jan I i Onufr, który ze wszystkich was wileńskich za stołem Masy najnudniejsze prowadzą życie, równać się ze mną nie mogą [...]" [List Adama Mickiewicza do Filomatów, Kowno, 27 stycznia/8 lutego 1820, w: A. Mickiewicz, Listy, cz. 1, Warszawa 1955, red. J. Krzyżanowski, s. 80].
} 
raz odwiedzają. Rukiewicz natomiast $\mathrm{w}$ listach do przyjaciół z właściwym sobie zapałem pisze o tym, jak to poczucie wyizolowania irytuje go ${ }^{19}$, jest więc nie tyle poetycko rozrzewniony, co zniecierpliwiony podobnym stanem rzeczy. Donosi też, że na skutek pozostawienia go samemu sobie nie może pracować tak efektywnie, jak by chciał. $W$ obu przypadkach przeżywana samotność ma zupełnie inne skutki - Mickiewicz zdaje się być wówczas jeszcze płodniejszym poetą, Rukiewicz natomiast, pomimo deklarowanych trudności, na przekór przeszkodom, zakłada coraz liczniejsze towarzystwa. Samotność, wbrew pozorom, służy obu filomatom, każdemu zgodnie z jego usposobieniem: Mickiewicz-poeta wykorzystuje talent we właściwy sobie sposób, jak przystało na artystę, przy pomocy pióra, zaś Rukiewicz-gospodarz, szlachcic, działacz w obliczu wyzwania pracuje jeszcze gorliwiej.

Nie tylko wiejska prowincja stanowi pole aktywności Michała Rukiewicza - istotnym miejscem w jego życiu prywatnym, jak i w filomackiej działalności, pozostawał Białystok. Stało się tak nie tylko dlatego, że w tym właśnie mieście znajdował się dom Rukiewiczów, ważna była przede wszystkim sama pozycja jego rodziny w Białymstoku oraz rozwinięte na szeroką skalę kontakty, szczególnie w kręgach urzędniczych i oświatowych. Rukiewicz należał bez wątpienia do osób rozpoznawalnych w społeczności białostockiej - jako syn urzędnika, uczeń tutejszego Gimnazjum, następnie uczestnik kampanii napoleońskiej i wreszcie absolwent Uniwersytetu Wileńskiego, wytworzył sobie rozliczne stosunki towarzyskie. O tym, że był on osobą rozpoznawalną, świadczą m.in. zapisy w metrykach chrzcielnych, potwierdzające koneksje towarzyskie podlaskiego filomaty. Tę nieprzypadkową funkcję - ojca chrzestnego - pełnił Rukiewicz wielokrotnie, należał więc do osób, $\mathrm{z}$ którymi warto było pozostawać $\mathrm{w}$ dobrych relacjach. W dokumentach znajdujemy m.in. następujące informacje: „Rukiewicz jako asystent przy chrzcie Wiktorii, córki Franciszka Kramkowskiego i Antoniny Rukiewicz, dn. 5 stycznia 1822 r. chrzest w białostockim kościele" ${ }^{20}$ oraz "Michał Rukiewicz jako ojciec chrzestny Emilii Franciszki, córki Franciszka Kramkowskiego i Antoniny Rukiewicz, dnia 15 lutego 1824 r." ${ }^{21}$.

Można z dużą dozą prawdopodobieństwa przyjąć, że podczas studiów Michał Rukiewicz regularnie odwiedzał Białystok, co wynikało z konieczności wspierania sióstr, które zajmowały się domem pod nieobecność brata. Świadczy też o tym bardzo dobre zorientowanie Rukiewicza w życiu mia-

\footnotetext{
19 „Szkoda, że z was który choć raz nie spróbował, co to jest siedzieć na prowincyi i jaka to łatwość wynaleźć ludzi, a znalazłszy, jak to łatwo zachęcić ich do zabawy" [KF IV, s. 345].

20 Litewskie państwowe Archiwum Historyczne w Wilnie, f. 604, op. 58, d. 15, nr 26.

21 Litewskie państwowe Archiwum Historyczne w Wilnie, f. 604, op. 58, d. 17, nr 72.
} 
sta - jego spostrzeżenia zapisane zostały w listach do przyjaciół, wysyłanych niedługo po opuszczeniu uniwersyteckich murów. Najwięcej informacji na temat związków Rukiewicza z Białymstokiem pojawia się od roku 1821, kiedy to absolwent Uniwersytetu Wileńskiego zaczął wcielać w życie filomacki plan dydaktyczny. Jednak już w lipcu 1820 roku, a więc kilka tygodniu po opuszczeniu Wilna, Rukiewicz w liście pisanym do Onufrego Pietraszkiewicza przedstawia swój pogląd na postępy w krzewieniu przyjętych przez Towarzystwo ideałów wśród podlaskiej młodzieży oraz na poziom zaangażowania $\mathrm{w}$ to zadanie Zygmunta Nowickiego, białostockiego nauczyciela, absolwenta Uniwersytetu i ucznia Joachima Lelewela:

Trzy dni tego miesiąca to jest 10, 11 i 12 bawiłem w Białymstoku. Widziałem się tam z Nowickim i Sobolewskim. Byliśmy z Janem u Nowickiego, któren narzekał, że bracia nie mają względu na jego czynności, których dowody przesłał niedawno na piśmie do Wilna, lecz uważają go za próżniaka. Mówił nam, iż w tym roku dawał gratis historią polską dla całego gimnazjum, że na to zezwolił uniwersytet, że ma tym sposobem wiele zręczności wpojenia w młodzież podlaską ducha dobrego. Czytał nam dość krótką wprawdzie, lecz ożywiającą przemówkę, którą miał przy zaczęciu wspomnianego kursu, chcąc siebie wymówić, dlaczego dotykalniej czynności swoich widzieć nie daje; że wojskowi tu konsystujący, mają zwrócone oczy na młodzież, że przeto nic z nimi przedsiębrać nie można. Lecz zbyteczną tę czułość małemu egoizmowi i niewielkiemu lenistwu naszego brata przypisać należy [KF II, s. 197-198] ${ }^{22}$.

Rukiewicz jako jedyny spośród filomatów zdaje się z tak wielkim zaangażowaniem realizować zrodzony jeszcze $\mathrm{w}$ Towarzystwie plan kształcenia młodzieży - to jemu udaje się wcielić w życie założenia dotyczące rozpowszechniania "specjalistycznych" czasopism, stowarzyszania młodych oraz rozbudzania polskiego ducha narodowego - mowa tu oczywiście o narodowości w ujęciu dziewiętnastowiecznym, przedetnicznym:

Dzisiaj mówimy raczej o świadomości narodowej, charakterze narodowym itp. [...]. Narodowość była bowiem w początkach XIX wieku pojęciem bardzo szerokim, nadrzędnym, obejmującym szereg cech szczególnych danego narodu, jak charakter narodowy, zwyczaje i obyczaje, język oraz kult przeszłości. Używając pojęcia narodowość mówiło się zatem o całym szeregu zjawisk z dziedziny ideologii i kultury, określających indywidualność narodu ${ }^{23}$.

${ }^{22} \mathrm{~W}$ tym samym liście Rukiewicz interesująco opisuje też własne usposobienie w porównaniu do zachowania Mickiewicza.

23 A. Witkowska, Rówieśnicy Mickiewicza. Życiorys jednego pokolenia, Warszawa 1962, s. 255. Witkowska przywołuje też definicję narodowości z epoki, zamieszczoną w artykule $O$ narodowości, który ukazał się na łamach czasopisma „Dekada Polska” (nr 3 z 1821 r.): „narodowością 
Przeciwko polskiej świadomości narodowej, tak bliskiej Rukiewiczowi, występował Nowosilcow podczas śledztwa w Wilnie, tym ważniejszy jest więc czas pracy nad wytworzeniem podobnej postawy, a tym samym znaczniejsza okazuje się rola podejmowanych przez Rukiewicza działań na Podlasiu. M.in. za sprawą jego zapału owa świadomość miała szansę rozbudzić się również na prowincji. Późniejszy dzierżawca majątku w Zawykach starał się też aktywizować szlachtę podlaską - nie zawsze chyba w celach spiskowych, raczej samorządowych, obywatelskich (z perspektywy władz zaborczych - jednak wrogich) - i zabiegał, by społeczność znajdująca się pod jego „kuratelą" miała dostęp do odpowiedniej literatury. W jednym z listów do Franciszka Malewskiego podlaski filomata zaznacza, że pośród "ochotników do zabawy" są też damy, a z tego względu należy uważnie dobierać prenumerowane pisma:

Proponowane przez ciebie wspólne czytanie pism periodycznych może się da w obłaci białostockiej przynajmniej zaprowadzić. Kilka tentacyi w tej mierze moich jakąż kolwiek robią mi nadzieję. Ponieważ pomiędzy ochotnikami do zabawy tego rodzaju są i damy, chciej więc mnie kilka pism periodycznych wymienić w językach polskim i francuskim, w których by szczególniej polityka, gospodarstwo i poezja znaleźć się mogły, słowem, takie, które by różnej płci, wiekowi i stanowi naszej szlachty podobać się mogły [KF III 379].

Aktywność filomaty nie byłaby jednak tak skuteczna, gdyby nie jego zorientowanie w sprawach miasta i pewna rozpoznawalność w Gimnazjum Białostockim. Świadczy o niej chociażby list pisany 6 sierpnia 1821 do Czeczota, w którym Rukiewicz przekazuje zarówno już znane mu fakty z życia Gimnazjum, jak i rozważa dość szczegółowo dotyczące go plany:

Dowiedz się od kogo bądź z rządowych uniwersytetu, jakie odmiany zajdą co do nauczycieli w gimnazjum białostockiem. Piszę na dzisiejszą pocztę do rektora, przypominając mu jego przyrzeczenia. Dowiedz się szczególniej, czy nauczyciel Antecki utrzyma się tu na rok przyszły. Postępowanie jego, dość dobrze znajome rektorowi, czyni go bardzo szkodliwym dla tutejszego gimnazjum; jeśli Jarosz [Malewski - dop. M.D] może, niech się stara o jego odmianę, szczególniej, że ojciec Jarosza najsolenniej mi to przyrzekł. Dowiedz się takoż, kiedy wyjdzie rezolucja na moją prośbę, do uniwersytetu podana. Oznajm kto z naszych znajomych jest $\mathrm{w}$ Wilnie [...]. Trudnię się teraz czytaniem i poznawaniem osób,

\footnotetext{
są cechy właściwe odróżniające jeden naród od drugiego. Są one dwojakie; pochodzą albo ze sposobu myślenia i czucia, czyli charakteru narodowego, albo z zewnętrznych oznak, czyli języka i zwyczajów. Ob[y]dwie stanowią najpewniejszą warownię szczęścia narodowego, bo są najzdolniejsze do żywienia w sercach przywiązania do kraju, do rządu co je zabezpiecza i do współziomków, których charakter i zewnętrzność łączy".
} 
które mogą być dla mnie pożyteczne z czasem. Zbieram materiały do wiadomości statystycznych. Żaden ze znajomych naszych w tych okolicach będących, nie widuje się ze mną. Wszyscy ci, co mają być $\mathrm{z}$ tego gimnazjum $\mathrm{w}$ uniwersytecie, są mi po części znajomi; lepiej ich na większym świecie poznać będzie można [KF III, s. 397-398].

Tak drobiazgowa sprawozdawczość wobec toczących się wokół Rukiewicza zdarzeń, również jeżeli chodzi o przygotowywany przez niego „opis statystyczny", stanowiący ważny wątek w procesie filomatów, jest kolejnym przejawem szczególnego związku Rukiewicza z Podlasiem - zdaje się on wiedzieć o każdej znaczniejszej decyzji podejmowanej czy to w murach Uniwersytetu, czy białostockim Gimnazjum.

Michał Rukiewicz był odpowiednią osobą do tego, by stać na straży praw i moralności (zgodnie zresztą z kierunkiem podjętych przez niego studiów), co wynika z rozwiniętego zmysłu odpowiedzialności za otoczenie i świadomości specyfiki miejsca, w którym przyszło mu żyć. Dobra orientacja Rukiewicza w sprawach całej Litwy dochodzi do głosu we wrześniu 1821 roku, kiedy to w liście do Czeczota pojawiają się pytania zarówno o powód wizyty Pelikana w Wilnie, jak i o informacje dotyczące kandydatów do stanu nauczycielskiego, o nazwiska dyrektorów w Krzemieńcu, Wilnie i Mińsku. Ponadto dopytuje on o przegląd wojsk, stan Towarzystwa Filomatów i dla dopełnienia całości obrazu nie zapomina też zapytać o czas przybycia profesorów Lelewela i Gołuchowskiego [KF IV 20-21]. Oczywiste jest, że Rukiewicz chce wiedzieć jak najwięcej o sposobie życia wileńskich przyjaciół, czy to z powodu tęsknoty, czy po prostu ze względu na chęć podtrzymania dobrych relacji. Nie sposób jednak pominąć i tego, że większość kontaktów stara się możliwie najskuteczniej wykorzystać na Podlasiu, czy to prosząc o dodatkową prenumeratę pism periodycznych, czy radząc się w sprawach związanych $\mathrm{z}$ prowadzeniem towarzystw. Autor $\mathrm{Pa}$ cierza promienistego $\mathrm{w}$ ten sposób zbliża podlaską prowincję do wileńskiego centrum, tworząc z obu miejsc przestrzenie komplementarne i skomunikowane ze sobą. Czyni tak chociażby przez traktowanie Wilna jako miejsca, do którego w każdej chwili można pojechać i zatrzymać się tam, zarówno dla załatwienia koniecznych spraw, jak i pokrzepienia się obecnością współtowarzyszy. Nie bez powodu Rukiewicz zaznacza przecież w tym samym liście: „Kazimierzowi powiedz niech ma dla mnie stancją" [KF IV, s. 20-21]. Tak uważna i „czuła” na topograficzny konkret korespondencja staje się kolejnym pomostem pomiędzy prowincją a wileńskim centrum. Natomiast wszystkie zdobyte tą drogą informacje pozwalają Rukiewiczowi realizować cel przyjęty już na początku studiów i skrupulatnie wcielany w życie w kolejnych latach - 
była nim dbałość o formowanie świadomości obywatelskiej młodzieży i podlaskiej szlachty.

Na uwagę zasługuje również merytoryczne przygotowanie Rukiewicza do pełnienia powierzonej mu (czy też pełnionej z własnej inicjatywy) funkcji: czytanie, zbieranie materiałów do statystyk zdaje się być głównym zajęciem „Szwaliżera", co podkreśla tylko jego wyjątkową sumienność. Nie przykładał się bowiem zbytnio, jak relacjonowali inni filomaci, do teorii naukowych, wolał użytecznie je stosować - na fakt ten zwróciła uwagę również Alina Witkowska, ukazując jego styl życia na wsi. Według przyjaciół miał on po zakończonym dniu pracy zajmować się czytaniem notatek zachowanych jeszcze z wykładów prowadzonych przez profesora Lelewela. Podobna lektura zdawała się stać $\mathrm{w}$ sprzeczności $\mathrm{z}$ urzędniczo-gospodarskim trybem życia Rukiewicza ${ }^{24}$, jak się jednak okazuje, nabywanie wiedzy, która pomagała żyć i zmieniać otoczenie, nie tylko nie nastręczało mu trudności, ale też nie dziwiło jego uniwersyteckich przyjaciół.

Niezwykle cenna informacja na temat planów Rukiewicza, które dość szybko się urzeczywistniły, pojawia się w liście do Pietraszkiewicza pisanym w styczniu 1821 roku:

Bawię się najczęściej $\mathrm{w}$ Białymstoku, trudnię się nabywaniem potrzebnych do przyszłego stanu mego wiadomości. Mam nadzieję umieszczenia się przy księciu Lubeckim, ministrze skarbu; ale nie wiem jak mi się to uda. Jeżeli nie, to zostanę gospodarzem i nędznym $\mathrm{w}$ powiecie swoim urzędnikiem [KF IV, s. 133-134].

Prawdopodobnie nie na skutek niepowodzenia na drodze kariery urzędniczej, lecz raczej w wyniku dobrego rozeznania w owym "powiecie” oraz dzięki godnemu podziwu zmysłowi gospodarskiemu, Michał Rukiewicz $\mathrm{w}$ istocie decyduje się na wydzierżawienie folwarku w podbiałostockich Zawykach. O swojej decyzji informuje Pietraszkiewicza, martwiącego się najwidoczniej jakością życia osobistego Rukiewicza, co podkreśla następujące wyznanie: „wymawiasz mnie bezczynność; biorę amty, jak mogę; myślę o żonce, jak mogę - raczcie się tylko o tym z pewnych źródeł dowiedzieć" [KF V, s. 96]. „Amtami", jak czytamy w przypisie, „przezwali Prusacy dawne starostwa niegrodowe w białostockim obwodzie i wyraz się utrzymał, choć ziemie te przeszły pod panowanie rosyjskie" [KF V 96]. Wzięty (w maju) przez Rukiewicza w dzierżawę folwark Zawyki pochodził właśnie z suraskiego „amtu”, liczącego sobie jeszcze dwa inne folwarki: Baranki i Tryczówkę.

24 A. Witkowska, Rówieśnicy Mickiewicza, s. 186. 
Jak wynika z korespondencji, wieść o objęciu przez Rukiewicza gospodarstwa nieprędko dotarła do wszystkich jego przyjaciół, dzierżawca Zawyk szybko naprawia jednak to niedopatrzenie, wyjaśniając swoją sytuację w liście adresowanym do Kazimierza Piaseckiego ${ }^{25}$ :

Nazywasz mnie dziwakiem, że zostawszy oberamtmannem, nie oznajmuję, gdzie i przy jakim miasteczku mieszkam. Zdało mi się, że jak ja i moje sotniki, dziesiątniki, wójty i t. d. to wiedzą, tak i cały świat wiedzieć powinien, że trzymam amt Suraski, mieszkam w folwarku Zawyki o 3 mile od Białegostoku, gdzie często bywam i listy do mnie pisane z całą powagą oberamtmanna odbieram [...]. Spodziewam się, że jak się puścisz na wagabungę, np. podczas wakacji albo około ś. Józefa, jak zwykłeś na kontrakta wyjeżdżać, i do mnie zawitasz; co to będzie za radość, co za rozkosz! [KF V, s. 280-281].

Zawyki były miejscem dość regularnych odwiedzin filomatów - nie tylko przywołany list do Piaseckiego, ale też wiele innych przynosi informację o choćby chwilowym zatrzymaniu się w majątku przyjaciela. Pojawienie się folwarku wytworzyło więc dodatkową przestrzeń, w której nie tylko z powodzeniem odnalazł się Rukiewicz, wraz ze swoim gospodarskim okiem i umiejętnością zarządzania ${ }^{26}$, lecz także dokonało się odnowienie jego kontaktu ze środowiskiem wileńskim. Tak jak we wcześniejszym okresie swoich działań na prowincji Rukiewicz skarżył się na poczucie osamotnienia, tak teraz stał się gospodarzem, w którego dobrach „brama na wskroś otwarta” zapraszała w gościnę filomatów szukających miejsca do dzielenia się zdobytymi

25 Adresat jest tu niezwykle ważny, bowiem Piasecki podobnie jak Rukiewicz pracuje na prowincji, stąd łatwiej mu zrozumieć troski "Szwaliżera” niż pozostałym filomatom. Ton listów Rukiewicza do Piaseckiego zdecydowanie różni się od tych pisanych do Czeczota, Zana czy nawet Pietraszkiewicza. Listy do Piaseckiego pełne są nie tylko porad, komentarzy, ale też nie brak w nich utarczek słownych, są więc dużo swobodniejsze niż te pisane do wymienionych przeze mnie wcześniej filomatów. Może to wynikać z faktu, iż Piasecki nie należał do głównego trzonu Towarzystwa, stąd mniej oficjalny ton. Przyczyną może być jednak również wspólnota doświadczeń, większa świadomość w zakresie zakładania towarzystw właśnie na prowincji. Nie bez powodu Rukiewicz konsultuje się z Pietraszkiewiczem w kwestii działań podejmowanych przez Wincentego Zawadzkiego, zaznaczając, iż należy mu wyjaśnić specyfikę wiejskiego życia. Rukiewicz skrupulatnie informuje też Piaseckiego o wypadkach mających miejsce w Białymstoku, mówi bowiem: „W tydzień po wyjeździe z Wilna stanąłem szczęśliwie w Białymstoku. Piękna tu pogoda i dobrze się bawią. Po skończonym Wielkim Poście znowu wraca karnawał i choć dosyć ciepło, nic na to nie uważamy, tańcujemy". Opisywana przez Rukiewicza gorąca atmosfera panująca w mieście może (choć nie musi) być echem dziejących się w Wilnie zdarzeń z udziałem Nowosilcowa, który przecież miesiąc wcześniej "gościł" jeszcze w Obwodzie Białostockim. Por. List Rukiewicza do Piaseckiego, 11 maja 1823 [FP V, s. 211-213].

26 Życie w Zawykach obfitowało też niestety w różnego rodzaju trudności - w liście do Czeczota Rukiewicz skarży się na przykład na swoją niezwykle trudną sytuację finansową. Por. [KF V, s. 278-279]. 
doświadczeniami i wiedzą. Warto też zwrócić uwagę na to, że, wbrew wcześniejszym wyznaniom, Rukiewicz nie jest wcale "marnym gospodarzem" zarówno położenie folwarku, jak i jego wyposażenie świadczą raczej o wysokim standardzie majątku oraz o późniejszej przydatności umiejętności w nim zdobytych.

Posiadłość ${ }^{27}$ Michała Rukiewicza składała się z wielu budynków gospodarczych, została też w znacznej części zagospodarowana pod względem rolniczym - ogród oraz przestrzeń przeznaczona na uprawę roślin były niewątpliwie jednym ze źródeł utrzymania szlachcica i jego sióstr. Nie mniej ważne jest to, że Zawyki znajdowały się nad Narwią. Jak okazało się w późniejszych latach, połów ryb, który zapewne stanowił formę relaksu pośród codziennych obowiązków ziemianina, miał już na Syberii stanowić jego główne źródło dochodów. Poniższy plan gospodarstwa w Zawykach pozwala zdobyć jeszcze bardziej szczegółowe informacje dotyczące miejsca, w którym Rukiewicz prowadził swoją działalność:

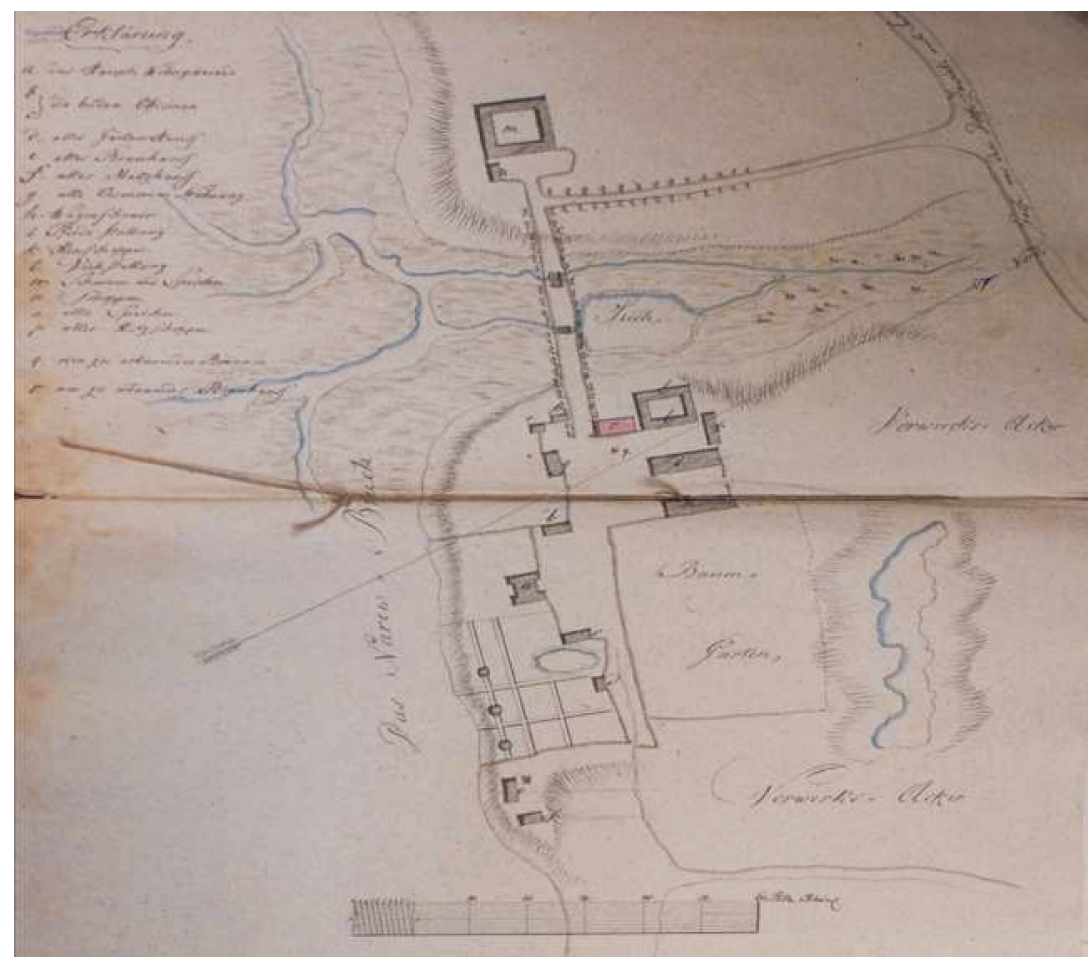

27 Na stworzenie dokładnego opisu gospodarstwa dzierżawionego przez Michała Rukiewicza w Zawykach pozwala mapa tego terenu, której skan znajduje się w Archiwum Państwowym w Białymstoku. 
Można się też domyślać, że mosty znajdujące się na rzece były miejscem częstych spotkań członków różnego rodzaju towarzystw - zarówno tych należących do wileńskiego Towarzystwa Filomatów, jak osób, które już na Podlasiu przyłączyły się do organizacji inicjowanych przez Michała Rukiewicza ${ }^{28}$.

Z Zawykami wiąże się też inne, niezwykle istotne wydarzenie, mówi o nim list Rukiewicza do Czeczota z 21 września 1823 roku:

Zamiar przybycia do mnie na mieszkanie Adama napełnił prawdziwą rozko-
szą niezmienne serce, którego zawsze jedynym celem i jedynym szczęśiem jest
przyjaźn. „Ile mu przykro jak mówisz, wycierać choć przyjacielskie kąty, ile pro-
pozycja ta dla niego niesmaczna”, tyle mu to wszystko prawdziwy przyjaciel
starać się będzie osłodzić. Nie dozna zapewne kochany Adam tych przyjemno-
ści, jakich mu Jan lub Tomasz dostarczyć mogą; ale się też przekona, że i Michał
równie, jak oni, przyjaciel, równej chęci widzenia jego szczęśliwym. Choć przy
mniejszych zdolnościach, tyle jednak smacznym pobyt Adama na wsi uczyni,
że nie powie, iżby czyje kąty wycierał.
Pod koniec tego lub na początku przyszłego miesiąca będzie w Wilnie z Bia-
łegostoku WPan Maciejewski, naczelnik stołu w tutejszej Izbie skarbowej, dobrze
mi znajomy, dobry i rozsądny człowiek. Z małym bardzo ekspensem zabierze
się z nim Adam. Mówiłem mu o tym; chętnie się zgadza. Przez niego do ciebie
napiszę. Niech Adam przyjeżdża kiedy zechce, i prędzej; czekam go zawsze
z otwartymi rękoma [...] [KF V, s. 336].

List ważny jest z kilku powodów. Przede wszystkim planowane spotkanie byłoby pierwszą wizytą Mickiewcza w okręgu białostockim - nigdy dotąd poeta nie odwiedził Rukiewicza, wymienili ze sobą jedynie kilka listów. Poza tym, korespondencja pochodzi $z$ okresu, w którym nie jesteśmy w stanie dokładnie określić miejsca pobytu Mickiewicza, wiadomo jedynie, że w cieniu toczącego się w Wilnie śledztwa Nowosilcowa filomaci ustalali między sobą, jakie lokalizacje byłyby najlepsze do zatrzymania się. Mickiewicz wprawdzie podejmuje decyzję o przedłużeniu swojej pracy w Kownie, jednak nie wiadomo, czy pierwsze tygodnie września spędza już tam, czy też pozostaje

${ }^{28}$ Ciekawe jest również to, że trakt prowadzący do Zawyk - droga z obu stron otoczona drzewami - oraz sama organizacja przestrzeni przypominały w dużym stopniu Hoźną, rodzinną miejscowość filomaty, o czym świadczą m.in. zdjęcia zamieszczone przez Stanisława Niewińskiego w książce Pokój cieniom [zob. S. Niewiński, Pokój cieniom. Ziemi Juchnowieckiej historie nieokrzyczane, Juchnowiec Kościelny 2014]. Zapewne jest to wynikiem powszechnego wówczas sposobu zagospodarowywania przestrzeni, jednak pewna analogia pomiędzy ziemią, którą Rukiewicz, jako syn szlachcica, miał odziedziczyć (co jednak na skutek zmiennych okoliczności życiowych okazało się niemożliwe), a tą, którą w wyniku podjętych przez siebie decyzji nabył, warta jest odnotowania. 
w Wilnie ${ }^{29}$, tym bardziej interesujące są więc świadectwa tego, że rozważano również możliwość przyjazdu poety na Podlasie. Niestety, pełne nadziei oczekiwania Rukiewicza okazały się próżne - nie udało się doprowadzić do przyjazdu przyjaciela, którego utwory (prenumeratę) z wielką gorliwością rozprowadzał w swoim obwodzie. W kilka tygodni po nadaniu cytowanego powyżej listu podlaski filomata dowiaduje się o aresztowaniu Mickiewicza i pozostałych bliskich mu osób - dla wszystkich członków Towarzystwa zaczyna się czas szczególnej weryfikacji tak podejmowanych działań, jak i łączącej ich więzi.

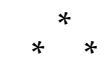

Odmienną postawę wobec miejsca swojej „pouniwersyteckiej” działalności przyjmuje natomiast Mickiewicz - „miejsce zamieszkania” nie jest dla niego przestrzenią „praktykowania” idei filomackiej, lecz raczej przeżywania i zapisywania stanów wewnętrznych. Doświadczenie Mickiewicza można opisać w kategoriach geografii emotywnej ${ }^{30}$ : każda zmiana skutkowała dużym nakładem emocjonalnym, przez pryzmat uczuć czytał/poznawał on kolejne miejsca. Zarówno wspomnienia dotyczące wierszowanego opisu pożaru Nowogródka, jak i wiersz Zima miejska, a także ton listów filomackich przyjaciół wskazują, że przestrzenna biografia Mickiewicza tworzona jest głównie przy pomocy emocji i pióra, nie zaś, jak w przypadku Rukiewicza - planowania i działania (wyjazdów w teren). Ów zwyczaj poetyckiego „zapisywania miejsc", poparty ekspresją emocji w listach, wydaje się tym godniejszy dostrzeżenia, jeśli zatrzymamy się nad przestrzenią, której Mickiewicz nie zdecydował się utrwalić w swojej twórczości - mowa tu o Kownie. Brak literackiego świadectwa topograficznego jest niemal równoznaczny z wyparciem samego przeżycia biograficznego. Miejsce w świecie i miejsce $w$ doświadczeniu biograficznym pozostają ze sobą w silnym związku, jeżeli więc określone miejsce geograficzne - $\mathrm{w}$ tym przypadku Kowno - konotuje negatywne emocje, więź z nim zostaje zerwana, co skutkuje nieumiejscowieniem, przemilczeniem „traumatycznej przestrzeni" w biografii.

29 Por. M. Dernałowicz, K. Kostenicz, Z. Makowiecka, Kronika życia i twórczości Mickiewicza. Lata 1798-1824, Warszawa 1957, s. 438-439 oraz Z. Sudolski, Mickiewicz, Warszawa 1995, s. 142. Równie prawdopodobny jest też wyjazd poety nad Morze Bałtyckie dla poprawienia zdrowia.

30 Geografia emotywna ma wskazywać na związki zachodzące pomiędzy emocjami, literaturą a przestrzenią. Elżbieta Rybicka, pisząc o geografii emocji i topografii emotywnej (emocjonalnie nacechowanych opisów miejsc i przestrzeni geograficznych), podkreśla m.in. zwrot w stronę afektów i relacji pomiędzy doświadczającym podmiotem a miejscem [zob. E. Rybicka, Geopoetyka, s. 267-276]. 
Z kolei w listach Mickiewicza do wileńskich kolegów nakreślony został wizerunek Kowna jako miejsca dynamicznego - ów dynamizm wiąże się właśnie ze zmiennością stanów emocjonalnych początkującego nauczyciela, a przy tym osamotnionego filomaty, stanów, które bezpośrednio wpływają na odbiór miasta. Najpierw Mickiewicz dość dobrze odnajduje się w nim, pośród pedagogicznych obowiązków, które zdają się wzbudzać jego zainteresowanie i wzniecać zapał dydaktyczny. Świadczy o tym chociażby fragment korespondencji do Jeżowskiego: „,jedyną prac szkolnych nagrodą jest pożytek i miłość uczniów; jedno idzie za drugim. Postanowiłem dawać lekcje jak można najlepiej" ${ }^{31}$. W listach Mickiewicza można raczej odnaleźć (pośród częstych narzekań) świadectwo woli przetrwania w uciążliwym miejscu niż filomackie zatroskanie o rozwój nauki, zwłaszcza wśród młodzieży. Nie wynika z nich, by nauczanie (a także swego rodzaju uspołecznienie podopiecznych, wspieranie ich, rozwijanie poczucia wspólnotowości) najbardziej poetę zajmowały. Realizacja tego zadania stała się natomiast życiowym celem Michała Rukiewicza, który w szkole nie pracował. Dla Mickiewicza powinności szkolne, do których zobowiązywało go pobierane podczas studiów stypendium, były raczej sposobem na poradzenie sobie z przymusową sytuacją, chwilę wcześniej donosił bowiem Jeżowskiemu: „umarłbym w miesiąc z nudy, gdyby nie wy i nie nawał pracy" ${ }^{32}$.

$\mathrm{Na}$ brak zajęć istotnie Mickiewicz nie mógł narzekać, prowadził 20 godzin lekcji tygodniowo - w klasach III i IV uczył gramatyki polskiej, w klasie V historii literatury łacińskiej, w klasie VI historii literatury polskiej, historii powszechnej oraz prawa. Oprócz tego przygotowywał seksterny, co również wymagało od niego dużego zaangażowania. Prócz znajomości z rodziną doktora Kowalskiego, jedynie prowadzenie lekcji w jakimś stopniu łączyło Mickiewicza z życiem społeczności kowieńskiej, godziny wolne od pracy spędzał samotnie, w wynajętym mieszkaniu, gdzie $\mathrm{z}$ upodobaniem obserwował domowe zwierzęta. O ile pies i kot w izbie nauczyciela nie dziwiły sąsiadów, to jednak utrzymywany wraz z nimi wąż budził już zainteresowanie i musiał czynić nowo przybyłego absolwenta Uniwersytetu lokalnym oryginałem.

Wraz z upływem czasu Kowno jawi się jako przestrzeń niewarta uwagi, w której już sam krajobraz wpędza autora Ballad i romansów w nastrój nabierający wręcz cech depresyjnych. Mickiewicz mimochodem donosi w jednym ze swoich listów, że wprawdzie w mieście znajduje się jakiś teatr, jednak był w nim tylko raz - taka z pozoru marginalna wzmianka pozwala zauważyć, że ciągłym punktem odniesienia jest dla poety ukochane Wilno. Wszak to

\footnotetext{
31 A. Mickiewicz, Dzieła, t. 14, Warszawa 1955, red. J Krzyżanowski, s. 28.

32 Tamże.
} 
w nim, kiedy tylko nadarzała się okazja, wolny czas spędzał w teatrze, a jeśli (z powodu braku funduszy) nie było to możliwe, korzystał z informacji zawartych w "Kurierze Litewskim”, skąd dowiadywał się wszystkiego o programach teatralnych, zapoznawał się też z recenzjami wystawianych sztuk.

Mickiewiczowskie Kowno należy więc do nielicznych miejsc, które, bez wątpienia, stanowiąc ważną przestrzeń w biografii poety, nie znalazło swojego odbicia w żadnym utworze jego autorstwa. Jedyne, migawkowe odzwierciedlenie sytuacji kowieńskiej znajdziemy w autobiograficznym wierszu To lubię, gdy Mickiewicz opisuje swoje przeżycia emocjonalne wywołane pobytem na odległej prowincji ${ }^{33}$. Nie ma natomiast w jego twórczości reprezentacji literackiej dziewiętnastowiecznego Kowna. W Konradzie Wallenrodzie znajdujemy jedynie opis czternastowiecznego miasta, stanowiący dowód zainteresowania Mickiewicza historią Litwy, a nie kowieńską przestrzenią.

Mickiewicz wciąż zdawał się myślą wracać do Wilna, z przebywającymi w tym mieście przyjaciółmi łączyła go czytana w tym samym czasie literatura, uwagi wymieniane na temat funkcjonowania organizacji, a także dzielone korespondencyjnie przeżycia.

Rukiewicz zaznaczał swoją obecność w poszczególnych miejscowościach działaniem, Mickiewicz - pisaniem. Podlaski filomata sukcesywnie utwierdzał się w przekonaniu, że "dać siebie ojczyźnie miło", gdy tymczasem do litewskiego poety nadal więcej mówiły "czucie i wiara".

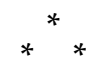

$\mathrm{W}$ ten sposób, $\mathrm{z}$ jednej strony poprzez ciągłą pracę na rzecz lokalnych społeczności i praktykowanie prowincji, z drugiej przez gest twórczy, literackie utekstowienie, powstawały odrębne geobiograficzne mapy dwóch filomatów.

Współtworzona przez szlaki życia mapa ${ }^{34}$ przedstawia nie tylko trasy przemieszczeń obu filomatów w latach 1812-1829, lecz staje się swego rodzaju tekstem, z którego można odczytać zarówno znaczenie określonych miejsc (np. bardziej pokoleniowe, w których "szlaki życia” krzyżują się lub bardziej indywidualne, wspólnotowe bądź samotnicze), jak i zastanowić się nad sposobem postrzegania przestrzeni przez Michała Rukiewicza oraz Adama Mickiewicza.

33 Por. A. Mickiewicz, To lubię, w: tegoż, Wiersze, Warszawa 1955, red. J. Krzyżanowski, s. $135-140$.

34 O nowym odczytywaniu map zob. m.in.: E. Konończuk, Mapa w interdyscyplinarnym dialogu geografii, historii i literatury, "Teksty Drugie” 2011, nr 5 oraz M. Dajnowski, Mapy literackie - kłacze, fałdy $i$ "efekt przedpokoju”, "Białostockie Studia Literaturoznawcze” 2016, nr 8. 


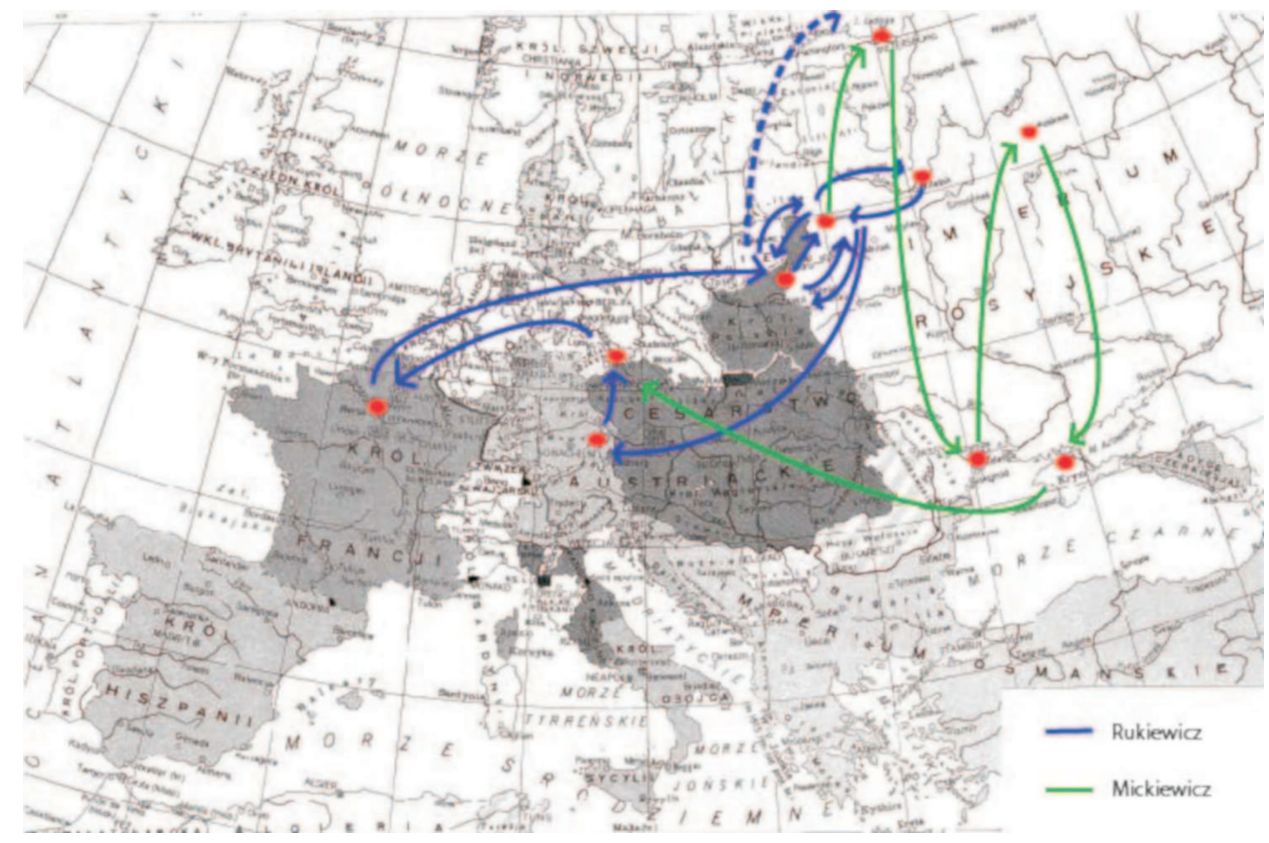

Ryc. 1. Geobiograficzne szlaki życia Michała Rukiewicza i Adama Mickiewicza

Bez wątpienia Wilno (oraz jego okolice) stanowić będzie na powyższej mapie pole najczęstszego przecinania się obu szlaków życia - Michał Rukiewicz wręcz bezustannie pokonuje trasę dzielącą je od Białegostoku, głównie po to, by zdobytą $\mathrm{w}$ centrum wiedzę w sposób praktyczny wykorzystać na Białostocczyźnie. Dla Mickiewicza natomiast, do chwili przymusowego wyjazdu do Rosji, Wilno i leżące blisko niego miejscowości (z wyjątkiem pobytu w Połądze) stanowią przestrzeń zupełną jego działań - dopiero wraz z ogłoszeniem wyroku, Mickiewiczowska perspektywa ulega niebagatelnemu poszerzeniu. Inaczej rzecz ma się z zarysowanym na mapie biograficznym szlakiem podlaskiego filomaty - jeszcze przed związaniem się z Wilnem Rukiewicz przemierza znaczną część Europy w szeregach Wielkiej Armii, choć dokładna marszruta "Szwaliżera”" czeka jeszcze na odtworzenie. Jednak również i on, podobnie jak Mickiewicz, trafi na owej mapie do punktu, w którym jego bezustanna podróż dobiegnie końca - dla Rukiewicza będzie to niewielka miejscowość położona na Syberii.

Interesujące jest jednak to, $\mathrm{z}$ jaką topografią doświadczonego świata obaj filomaci przyjeżdżają do Rosji. Mickiewicz ma z pewnością wyryty w pamięci plan Wilna i „nowogródzkiej strony”, następnie, wraz z upływającym czasem, ów młodzieńczy obraz poszerza się o doświadczenie rozległej Rosji, by dopiero w dalszej kolejności mogły zostać otwarte pozostałe granice - 
tym samym Mickiewicz dochodzi do „pełnej” eksploracji Europy. Taki sposób poznawania przestrzeni wyrażony jest w kolejnych utworach bądź relacjach z podróży, Mickiewicz bowiem zachwyca się nowo odkrytymi dla siebie miejscami.

Michał Rukiewicz zupełnie inaczej tworzy swoją „prywatną" mapę Europy. Kolejne państwa poznaje według żołnierskiego rytmu, co później zamiast poetyckiego opisu wyrazi krótkim: „byłem u brzegu Sekwany" 35 . W podobny, niezwykle konkretny sposób Rukiewicz planuje też swoje działania $\mathrm{w}$ rodzinnych stronach - jest człowiekiem, dla którego daleki świat, wędrówka, poznawanie nowych państw / kultur wiązały się już z przeduniwersyteckim etapem biografii, potem zaś - zesłańczym. Mickiewicz dopiero w momencie wyjazdu do Rosji uczy się działania przestrzennego, oswajania obcych miejsc, dopiero wówczas ma szansę na poszerzenie swojej prywatnej mapy, rozbudowanie geobiografii, podczas gdy Rukiewicz w chwili wyjazdu na Syberię już posiada ową zdolność. Michał Rukiewicz w pewnym stopniu (oczywiście nieświadomie) toruje też drogę Mickiewiczowi, ten bowiem w przyszłości odwiedzi państwa, które „Szwaliżer” poznał jako nastoletni młodzieniec.

„Szlaki życia” zapisane na mapie tworzą nietypowy obraz filomackiej, pokoleniowej geobiografii, którą tutaj reprezentują dwaj "spółuczniowie": bardzo znany i niemal zupełnie zapomniany. $Z$ jednej strony filomatyzm pozwoli bowiem nadać formę europejsko-napoleońskiemu doświadczeniu Michała Rukiewicza, z drugiej otworzy drzwi do Europy, przez Rosję, Adamowi Mickiewiczowi.

\section{Bibliografia}

Borowczyk Jerzy (2003), Rekonstrukcja procesu filomatów i filaretów 1823-1824, Poznań: Wydawnictwo Naukowe Uniwersytetu im. Adama Mickiewicza.

Borowczyk Jerzy (2014), Zesłane pokolenie: filomaci w Rosji (1824-1870), Poznań: Wydawnictwo Naukowe Uniwersytetu im. Adama Mickiewicza.

Bukczyn Siemion (1982), Echo pod Białymstokiem, przeł. A. Drawicz, Olsztyn: Wydawnictwo Pojezierze.

Czermińska Małgorzata (2011), Miejsca autobiograficzne. Propozycja w ramach geopoetyki, „Teksty Drugie”, nr 5, s. 183-200.

Czubek Jan [oprac.] (1913), Korespondencja filomatów, Kraków: Akademia Umiejętności i Towarzystwa dla Popierania Wydawnictw Akademii.

35 M. Rukiewicz,Wspomnienie, w: Poezje filomatów, t. 2, oprac. J. Czubek, Warszawa 1922, s. 223. 
Czubek Jan [oprac.] (1922), Poezja filomatów, t. 1, Warszawa: Akademia Umiejętności i Towarzystwa dla Popierania Wydawnictw Akademii.

Dajnowski Maciej (2016), Mapy literackie - kłacze, fałdy i „efekt przedpokoju”, „Białostockie Studia Literaturoznawcze", nr 8, s. 23-31.

Dernałowicz Maria, Kostenicz Ksenia, Makowiecka Zofia (1957), Kronika życia i twórczości Mickiewicza. Lata 1798-1824, Warszawa: Państwowy Instytut Wydawniczy.

Domańska Ewa (2012), Epistemologie pograniczy, w: Na pograniczach literatury, red. J. Fazan, K. Zajas, Kraków: Universitas.

Domańska Ewa (2014), Historia ratownicza, „Teksty Drugie”, nr 5, 12-26.

Dunajówna Maria (1935), Filomaci na prowincji, Wilno: Polska Drukarnia Nakładowa „Lux".

Dąbrowicz Elżbieta, Lul Marcin, Sawicka-Mierzyńska Katarzyna, Zawadzka Danuta [red.] (2015), Georomantyzm. Literatura, miejsce, środowisko Białystok: Wydawnictwo Uniwersytetu w Białymstoku.

Kaczmarek Jacek (2004), Geobiografia - historie życia a studia nad migracjami, „Acta Universitatis Lodziensis. Folia Geographica Socio-Oeconomica", nr 5, s. 47-57.

Konończuk Elżbieta (2011), Mapa w interdyscyplinarnym dialogu geografii, historii i literatury, „Teksty Drugie”, nr 5, s. 255-264.

Konończuk Elżbieta, Nofikow Ewa, Sidoruk Elżbieta [red.] (2014), Geografia i metafora, Białystok: Wydawnictwo Uniwersytetu w Białymstoku.

Mickiewicz Adam (1955), Dzieła, t. 14, Warszawa: Czytelnik.

Mickiewicz Adam (1955), Listy, cz. 1, Warszawa: Czytelnik.

Mickiewicz Adam (1955), Wiersze, Warszawa: Czytelnik.

Niewiński Stanisław (2014), Pokój cieniom. Ziemi Juchnowieckiej historie nieokrzyczane, Juchnowiec Kościelny: Stanisław Niewiński, ZNAKI Projektowanie Wydawnictw Drukowanych.

Rukiewicz Michał (1922), Wspomnienie, w: Poezje filomatów, t. 2, oprac. J. Czubek, Warszawa: Akademia Umiejętności i Towarzystwa dla Popierania Wydawnictw Akademii.

Rybicka Elżbieta (2014), Geopoetyka. Przestrzeń i miejsce we wspótczesnych teoriach i praktykach literackich, Kraków: Universitas.

Rzepczyński Sławomir (2007), Projekt „innego” biografizmu, „Słupskie Prace Filologiczne", nr 5, s. 171-176.

Škrabec Simona (2013), Geografia wyobrażona. Koncepcja Europy Środkowej w XX wieku, Kraków: Międzynarodowe Centrum Kultury.

Sudolski Zbigniew (1995), Mickiewicz: opowieść biograficzna, Warszawa: Ancher.

Trynkowski Jan (2002), Gimnazjum. Z dziejów Gimnazjum Białostockiego, Białystok: Polskie Towarzystwo Historyczne.

Tuan, Yi-Fu (1987), Przestrzeń i miejsce, przeł. A. Morawińska, wstęp K. Wojciechowski, Warszawa: Państwowy Instytut Wydawniczy.

Witkowska Alina (1962), Rówieśnicy Mickiewicza. Życiorys jednego pokolenia, Warszawa: Oficyna Wydawnicza Rytm.

Wróbel Wiesław (2016), Białostockie ślady Michała Rukiewicza, http://www.naszahisto ria.pl/artykuly/a/bialostockie-slady-michala-rukiewicza,9412089. 
Wróbel Wiesław (2016), Od Karola Zabłockiego do Michela Kona, http://www.poranny. pl/album-bialostocki/a/od-karola-zablockiego-do-michela-kona,9454915/.

Zan Tomasz (1916), Teoria promionków i majówki Promienistych, w: Promieniści - filomaci - filareci, oprac. H. Mościcki, Warszawa: Gebethner i Wolff, s. 47-52.

Zawadzka Danuta (2000), Pokolenie klęski 1812 roku. O Antonim Malczewskim i odludkach, Warszawa: Instytut Badań Literackich Polskiej Akademii Nauk.

Zawadzka Danuta (2014), Krajobraz, mapa, pejzaż - powinowactwa romantyczne, w: Geografia i metafora, red. E. Konończuk, E. Nofikow i E. Sidoruk, Białystok: Wydawnictwo Uniwersytetu w Białymstoku.

Zawadzka Danuta (2017), Białystok, w: Atlas Polskiego Romantyzmu, Nowa Panorama Literatury Polskiej, http://nplp.pl/artykul/bialystok-2/.

Litewskie państwowe Archiwum Historyczne w Wilnie, f. 604, op. 58, d. 15, nr 26.

Litewskie państwowe Archiwum Historyczne w Wilnie, f. 604, op. 58, d. 17, nr 72.

\title{
The Philomath Sense of Place: Fragments of Geobiographies of Michał Rukiewicz and Adam Mickiewicz
}

\begin{abstract}
The article discusses the relationships with places formed by two writers: Adam Mickiewicz and a forgotten Philomath from the region of Podlasie - Michał Rukiewicz. The author uses the methodologies developed within geopoetics and humanist geography to discover how the biography is related to a specific physical place and to demonstrate how the two writers shaped their geobiographies. Rukiewicz left his mark on the places with activism within local communities; Mickiewicz textualized them in artistic gesture. The Philomath from Podlasie was happy to give himself to his nation but the Lithuanian poet spoke more through emotion and faith.
\end{abstract}

Keywords: geopoetics, region, geobiography, autobiographical place, Philomaths 